\title{
ANALISIS KINERJA KARYAWAN PT. PUTRA KEDIANGAN PROPERTINDO
}

\author{
Irianto Loka ${ }^{1}$, Mahalayati² \\ Program Studi Manajemen Sekolah Tinggi Ilmu Ekonomi Gentiaras Lampung \\ Email: iriantoloka@gmail.com \\ Mahalayati96@gmail.com
}

\section{ABSTRACT}

This study is categorized as a census study. The type of data in this study is quantitative or numerical data. The instrument of this study using questionnaire. Population and sample in this research is all employees of PT. Putra Kediangan Propertindo of 32 employees. Sampling technique in this study using simple random sampling. Test the validity of the instrument using Confirmatory Factor Analysis while the reliability test using Alpha Cronbach. Measurers proved to be valid and reliable for research instruments. Multiple regression analysis was used to test the hypothesis of this study.

The results of research at the level of significance of $5 \%$ found that: (1) Job satisfaction has a positive and significant impact on employee performance PT. Putra Kediangan Propertindo, it is shown by the acquisition of $t$ test 2.070 with significance of 0.47. (2) Load work does not significantly affect the performance of employees of PT. Putra Kediangan Propertindo. This is shown by the acquisition of $t$ test 0.421 with significance of 0.677. (3) Job satisfaction and workload simultaneously have no significant effect on employee performance of Putra Kediangan Propertindo, it is marked from the acquisition of $F$ test obtained $F$ arithmetic 2,152 with significant level (p) 0,134a. The equation of employee performance variation determined by job satisfaction and workload is 12,9 percent ( $R$ sequare $=0,129)$. $R$ square number is 0,129 this means equal to $12,9 \%$ employee performance influenced by job satisfaction variable and work load. While the remaining $87.1 \%$ influenced by other factors outside this research variable.

Keywords: Job Satisfaction, Workload, Employee Performance

\section{PENDAHULUAN}

\subsection{Latar Belakang}

Berdasarkan pengamatan, kinerja karyawan PT. Putra Kediangan Propertindo perlu mendapatkan perhatian dan ditingkatkan. Hal ini dikarenakan terdapatnya beberapa karyawan dengan tingkat kehadiran yang masih rendah serta tidak adanya sanksi terhadap karyawan tersebut, dan penyelesaian tugas yang tidak tepat waktu. Berdasarkan hasil wawancara dengan beberapa karyawan diketahui bahwa fenomena tersebut terjadi disebabkan karena karyawan merasa harapannya atau yang menjadi keinginan karyawan seperti mendapat kompensasi tepat waktu tidak terpenuhi sehingga mengakibatkan karyawan merasa tidak puas. Sistem penggajian dalam perusahaan dinilai kurang efektif, karena terkadang gaji dibayarkan lewat dari tanggal seharusnya. Selain itu tugas dan tanggungjawab yang tidak jelas dan tidak merata juga menjadi beban kerja tersendiri bagi karyawan.

Selain kepuasan kerja, menurut hasil penelitian yang dilakukan oleh (Adityawarman, Bunasor dan Sinaga, 2015), beban kerja berpengaruh signifikan terhadap kinerja karyawan yang berarti bahwa beban kerja juga dapat mempengaruhi kinerja karyawan.

Dari sudut pandang ergonomi setiap beban kerja yang diterima harus sesuai dan seimbang baik terhadap kemampuan fisik, kemampuan kognitif maupun keterbatasan manusia yang menerima beban tersebut. Beban kerja dapat berupa fisik, mental atau sosial. Seorang tenaga kerja memiliki kemampuan tersendiri dalam hubungannya dengan beban kerja. Seorang karyawan mungkin ada yang lebih cocok dengan beban kerja fisik, mental atau sosial, namun sebagai 
persamaan, mereka hanya mampu memikul beban sampai suatu berat tertentu sesuai dengan kapasitas sewajarnya. Beban kerja yang semakin besar menyebabkan waktu seseorang dapat bekerja tanpa mengalami kelelahan atau gangguan semakin pendek.

Menurut (Manuaba, 2000), beban kerja yang terlalu berlebihan akan menimbulkan kelelahan baik fisik maupun mental dan reaksireaksi emosional seperti sakit kepala, gangguan pencernaan, dan mudah marah. Sedangkan pada beban kerja yang terlalu sedikit dimana pekerjaan yang terjadi karena pengurangan gerak akan menimbulkan kebosanan dan rasa monoton. Kebosanan dalam kerja rutin sehari-hari karena tugas atau pekerjaan yang terlalu sedikit mengakibatkan kurangnya perhatian pada pekerjaan sehingga secara potensial membahayakan pekerja. Oleh karena itu beban kerja yang harus dipikul setiap karyawan seharusnya sesuai dengan kemampuannya agar kinerjanya juga optimal.

\subsection{Perumusan Masalah}

1. Apakah kepuasan kerja berpengaruh signifikan terhadap kinerja karyawan PT. Putra Kediangan Propertindo?

2. Apakah beban kerja berpengaruh signifikan terhadap kinerja karyawan PT. Putra Kediangan Propertindo?

3. Apakah kepuasan kerja dan beban kerja berpengaruh signifikan terhadap kinerja karyawan PT. Putra Kediangan Propertindo?

\subsection{Tujuan Penelitian}

1. Untuk menganalisis apakah kepuasan kerja berpengaruh signifikan terhadap kinerja karyawan PT. Putra Kediangan Propertindo.

2. Untuk menganalisis apakah beban kerja berpengaruh signifikan terhadap kinerja karyawan PT. Putra Kediangan Propertindo.

3. Untuk menganalisis apakah kepuasan kerja dan beban kerja berpengaruh signifikan terhadap kinerja karyawan PT. Putra Kediangan Propertindo.

\section{TINJAUAN PUSTAKA}

\subsection{Kepuasan Kerja}

Kepuasan kerja merupakan sikap positif terhadap pekerjaan pada diri seseorang. Pada dasarnya kepuasan kerja merupakan hal yang bersifat individual. Setiap individu akan memiliki tingkat kepuasan yang berbeda-beda sesuai dengan sistem nilai yang berlaku pada dirinya. Biasanya orang akan merasa puas atas kerja yang telah atau sedang dijalankan, apabila apa yang dikerjakan dianggap telah memenuhi harapan, sesuai dengan tujuannya bekerja. Apabila seseorang mendambakan sesuatu, berarti yang bersangkutan memiliki suatu harapan dan dengan demikian akan termotivasi untuk melakukan tindakan kearah pencapaian harapan tersebut.

Kepuasan kerja didefinisikan sebagai sikap umum individu terhadap pekerjaannya (Robbins dan Judge, 2009). Dalam hal ini adalah karyawan. Karyawan dapat menilai seberapa puas atau tidak puas dirinya dengan pekerjaannya. Kepuasan kerja juga dapat digambarkan sebagai keadaan emosional karyawan yang terjadi maupun tidak terjadi titik temu antara nilai balas jasa kerja karyawan dan perusahaan atau organisasi dengan tingkat nilai balas jasa yang memang diinginkan oleh karyawan yang bersangkutan (Martoyo, 2000). Perusahaan harus mempertahankan kualitas dan melakukan inovasimempertahankan hubungan yang erat dengan pelanggandan membangun reputasi sehingga Mitsubishi L300 dapat mempertahankan loyalitas yang ada pada konsumennya (Yunada, 2015)

\section{Indikator Kepuasan Kerja}

Indikator kepuasan kerja yang digunakan dalam penelitian ini adalah indikatorindikator yang dikembangkan oleh (Celluci, Anthony $\mathrm{J}$ dan David L. De Vries dalam Mas'ud, 2004) yang meliputi antara lain:

a) Kepuasan terhadap gaji, yaitu senang atau tidak senang karyawan akan gaji yang diterima.

b) Kepuasan dengan promosi, yaitu sikap senang atau tidak senang karyawan akan promosi yang dilakukan perusahaan. 
c) Kepuasan terhadap rekan kerja, yaitu sikap senang atau tidak senang karyawan akan dukungan dari rekan kerjanya.

d) Kepuasan terhadap supervisor, yaitu sikap senang atau tidak senang karyawan akan perlakuan dari pimpinan.

\section{Ciri-Ciri Kepuasan Kerja}

Ciri pekerja yang memiliki kepuasan kerja menurut (Herzberg, 1959), ciri prilaku pekerja yang puas adalah mereka mempunyai motivasi untuk bekerja yang tinggi, mereka lebih senang dalam melakukan pekerjaannya, sedangkan ciri pekerja yang kurang puas adalah mereka yang malas berangkat ke tempat bekerja dan malas dengan pekerjaannya. Tingkah laku karyawan yang malas tentunya akan menimbulkan masalah bagi perusahaan berupa tingkat absensi yang tinggi, keterlambatan bekerja, dan pelanggaran disiplin yang lainnya. Sebaliknya tingkah laku karyawan yang merasa puas akan lebih menguntungkan bagi perusahaan. Menurut Nugroho (2015) Sektor Perdagangan bila dilihat dari kriteria angsuran dapat terindikasi macet. Melihat dari dua sektor diatas yang memiliki masalah pada pengembalian pinjaman, sektor industri sangat berbeda karena semua responden pengusaha industri, taat mengangsur dana pinjaman pada setiap periode angsuran kepada PTPN VII.

\subsection{Beban Kerja}

Menurut (Permendagri No. 12/2008), beban kerja adalah besaran pekerjaan yang harus dipikul oleh suatu jabatan atau unit organisasi dan merupakan hasil kali antara volume kerja dan norma waktu. (Prihartono dan Purwondoko, 2006), mengartikan beban kerja lebih merujuk pada seberapa tinggi persentase penggunaan waktu kerja produktif dan non produktif yang dilakukan karyawan jam kerjanya dengan tetap memperhitungkan kelonggaran karyawan.

Menurut (Munandar, 2001), beban kerja adalah keadaan dimana pekerja dihadapkan pada tugas yang harus diselesaikan pada waktu yang tertentu. Setiap pekerjaan merupakan beban bagi pelakunya.
Beban tersebut dapat berupa fisik, mental atau sosial. Seorang tenaga kerja memiliki kemampuan tersendiri dalam hubungannya dengan beban kerja. Mereka mungkin ada yang lebih cocok dengan beban kerja fisik, mental atau sosial, namun sebagai persamaan, mereka hanya mampu memikul beban sampai suatu berat tertentu sesuai dengan kapasitas sewajarnya. Beban kerja yang semakin besar menyebabkan waktu seseorang dapat bekerja tanpa mengalami kelelahan atau gangguan semakin pendek.

Menurut (Manuaba, 2000), beban kerja yang terlalu berlebihan akan menimbulkan kelelahan baik fisik maupun mental dan reaksireaksi emosional seperti sakit kepala, gangguan pencernaan, dan mudah marah. Sedangkan pada beban kerja yang terlalu sedikit dimana pekerjaan yang terjadi karena pengurangan gerak akan menimbulkan kebosanan dan rasa monoton. Kebosanan dalam kerja rutin sehari-hari karena tugas atau pekerjaan yang terlalu sedikit mengakibatkan kurangnya perhatian pada pekerjaan sehingga secara potensial membahayakan pekerja.

Dalam penelitian ini indikator beban kerja yang digunakan mengadopsi indikator beban kerja yang digunakan dalam penelitian yang telah dilakukan oleh (Putra, 2012) yang meliputi antara lain:

a. Target yang harus dicapai, yaitu pandangan individu mengenai besarnya target kerja yang diberikan untuk menyelesaikan pekerjaannya, misalnya untuk menggiling, melinting, mengepak dan mengangkut. Pandangan mengenai hasil kerja yang harus diselesaikan dalam jangka waktu tertentu.

b. Kondisi pekerjaan, yaitu mencakup tentang bagaimana pandangan yang dimiliki oleh individu mengenai kondisi pekerjaannya, misalnya mengambil keputusan dengan cepat pada saat pengerjaan barang, serta mengatasi kejadian yang tak terduga seperti melakukan pekerjaan ekstra diluar waktu yang telah ditentukan.

c. Standar pekerjaan, yaitu kesan yang dimiliki oleh individu mengenai pekerjaannya, misalnya perasaan yang 
timbul mengenai beban kerja yang harus diselesaikan dalam jangka waktu tertentu.

\subsection{Kinerja Karyawan}

Menurut (Simanjuntak, 2005), definisi kinerja adalah tingkat pencapaian hasil atas pelaksanaan tugas tertentu. Kinerja setiap orang dipengaruhi oleh banyak faktor yang dapat digolongkan pada tiga kelompok, yaitu kompetensi individu orang yang bersangkutan, dukungan organisasi, dan dukungan manajemen (Simanjuntak, 2005). (Mangkuprawira dan Hubeis (2007), menyatakan bahwa kinerja adalah hasil dari proses pekerjaan tertentu secara terencana pada waktu dan tempat dari karyawan serta organisasi bersangkutan.

Menurut (Sinambela dkk, 2012) mengemukakan bahwa kinerja pegawai didefinisikan sebagai kemampuan pegawai dalam melakukan sesuatu keahlian tertentu. Kinerja pegawai sangatlah perlu, sebab dengan kinerja ini akan diketahui seberapa jauh kemampuan pegawai dalam melaksanakan tugas yang dibebankan kepadanya. Untuk itu diperlukan penentuan kriteria yang jelas dan terukur serta ditetapkan secara bersama-sama yang dijadikan sebagai acuan.

Menurut pendapat (Mangkuprawira dan Hubeis, 2007) menyebutkan bahwa kinerja karyawan dipengaruhi oleh faktor intrinsik dan ektrinsik pegawai. Faktor-faktor intrinsik yang mempengaruhi kinerja pegawai terdiri dari pendidikan, pengalaman, motivasi, kesehatan, usia, keterampilan, emosi dan spiritual. Sedangkan faktor ekstrinsik yang mempengaruhi kinerja pegawai terdiri dari lingkungan fisik dan non fisik, kepemimpinan, komunikasi vertikal dan horizontal, kompensasi, kontrol berupa penyeliaan, fasilitas, pelatihan, beban kerja, prosedur kerja, sistem hukuman dan sebagainya.

Lebih lanjut (Mangkuprawira dan Hubeis, 2007) menguraikan faktor-faktor tersebut sebagai berikut:

1. Faktor personal, faktor personal pegawai meliputi unsur pengetahuan, keterampilan, kemampuan, kepercayaan diri, motivasi dan komitmen yang dimiliki oleh setiap individu.
2. Faktor Kepemimpinan, meliputi aspek kualitas manajer dan dan team leader dalam memberikan dorongan, semangat, arahan, dan dukungan kerja kepada karyawan.

3. Faktor Tim, meliputi kualitas dukungan dan semangat yang diberikan oleh rekan dalam satu team, kepercayaan terhadap sesama anggota team, kekompakan, dan keeratan anggota team.

4. Faktor Sistem, meliputi sistem kerja, fasilitas kerja dan infrakstruktur yang diberikan oleh organisasi, kompensasi dan proses organisasi dan kultur kinerja dalam organisasi.

5. Faktor Kontekstual, meliputi tekanan dan perubahan lingkungan eksternal dan internal.

Dalam penelitian ini penulis menggunakan beberapa indikator yang dikemukakan oleh (Tsui et al, dalam Mas'ud, 2004) antara lain:

1. Kuantitas kerja karyawan, yaitu jumlah yang dihasilkan dan dinyatakan dalam istilah seperti jumlah unit atau jumlah siklus aktivitas yang diselesaikan.

2. Kualitas kerja karyawan, yaitu ketaatan dalam prosedur, disiplin dan dedikasi. Tingkat dimana hasil aktivitas yang dikehendaki mendekati sempurna dalam arti menyesuaikan beberapa cara ideal dari penampilan aktivitas, maupun memenuhi tujuan-tujuan yang diharapkan dari suatu aktivitas.

\subsection{Hipotesis}

1. $\mathrm{H}_{01}$ : Kepuasan kerja tidak berpengaruh signifikan terhadap kinerja karyawan PT. Putra Kediangan Propertindo.

2. $\mathrm{H}_{02}$ : Beban kerja tidak berpengaruh signifikan terhadap kinerja karyawan PT. Putra Kediangan Propertindo.

3. $\mathrm{H}_{03}$ : Kepuasan kerja dan beban kerja tidak berpengaruh signifikan terhadap kinerja karyawan PT. Putra Kediangan Propertindo.

\section{METODE PENELITIAN}

\subsection{Jenis Penelitian}


Penelitian ini menggunakan pendekatan kuantitatif, dengan menggunakan metode sensus. Pengertian sensus adalah pengumpulan data apabila seluruh elemen populasi diselidiki satu per satu. Data yang diperoleh tersebut merupakan hasil pengolahan sensus disebut sebagai data yang sebenarnya ( true value ), atau sering disebut parameter.

\subsection{Populasi dan Sampel}

Menurut pendapat (Sugiyono, 2013), menyatakan bahwa yang dimaksud dengan populasi adalah suatu wilayah generalisasi yang terdiri dari objek atau subjek yang mempunyai kualitas dan karakteristik tertentu yang di tetapkan oleh penelitian untuk di pelajari dan kemudian di tarik kesimpulan. Maka populasi dalam penelitian ini adalah semua karyawan PT. Putra Kediangan Propertindo yang berjumlah 32 orang.

Menurut (Arikunto, 2010), jika subjeknya kurang dari 100 orang sebaiknya diambil semuanya, jika subjeknya besar atau lebih dari 100 orang dapat diambil $10-15 \%$ atau $20-25 \%$ atau lebih. Jumlah populasi dalam penelitian ini kurang dari 100 maka semua populasi dijadikan sampel penelitian sehingga sampel penelitian berjumlah 32 orang, oleh karena itu teknik sampling yang digunakan dalam penelitian ini adalah sampel jenuh, yaitu teknik penentuan sampel apabila semua anggota populasi digunakan sebagai sampel (Sugiyono, 2013). Dengan demikian responden dalam penelitian ini berjumlah 32 orang yang merupakan karyawan PT. Putra Kediangan Propertindo.

\subsection{Teknik Pengumpulan Data}

Dalam penelitian ini teknik pengumpulan data yang digunakan adalah Wawancara dengan melakukan wawancara kepada karyawan PT. Putra Kediangan Propertindo untuk mengetahui jumlah karyawan PT. Putra Kediangan Propertindo dan mendapatkan informasi yang berhubungan dengan kepuasan kerja, beban kerja, dan kinerja karyawan PT. Putra Kediangan Propertindo.

Kuesioner dalam penelitian ini mengadopsi kuesioner penelitian terdahulu, yaitu kuesioner yang dilakukan oleh (Artadi, 2015). Penyebaran kuesioner dalam penelitian ini dilakukan dengan menyebar langsung kuesioner yang berisi pertanyaan kepada responden. Dalam penelitian ini yang dimaksud responden adalah semua karyawan PT. Putra Kediangan Propertindo.

\subsection{Teknik Analisis data \\ 1. Uji Normalitas}

Menurut pendapat (Ghozali, 2013), uji normalitas bertujuan untuk menguji apakah dalam model regresi, variabel pengganggu atau residual memiliki distribusi normal. Uji normalitas yang akan dilakukan dalam penelitian ini menggunakan analisis statistik. Uji statistik dapat dilakukan dengan melakukan uji $\mathrm{P}-\mathrm{P}$ pi Oi

\section{Uji Homogenitas}

Uji homogenitas digunakan untuk mengetahui varian dari beberapa populasi sama atau tidak. Uji ini biasanya dilakukan sebagai prasyarat dalam analisi Independent Sampel $T$ Test dan Anova. Asumsi yang mendasari dalam Analisis of varians (ANOVA) adalah bahwa varian dari beberapa populasi adalah sama.

\section{Uji Statistik F}

Menurut pendapat (Ghozali, 2013), menyatakan bahwa uji statistik $F$ dimaksudkan untuk mengetahui apakah terdapat pengaruh yang signifikan secara simultan (bersamasama) antara variabel bebas terhadap variabel terikat. Jika nilai signifikan $>0,05$ maka dapat dikatakan bahwa tidak terdapat pengaruh yang signifikan antara variabel bebas terhadap variabel terikat secara simultan.

\section{Uji Statistik $t$}

Menurut pendapat (Ghozali, 2013), menyatakan bahwa uji statistik $t$ dimaksudkan untuk mengetahui apakah terdapat pengaruh yang signifikan secara parsial (sendiri-sendiri) antara variabel bebas terhadap variabel terikat. Dasar pengambilan keputusan dalam uji statistik $t$ adalah: Jika nilai signifikan > 0,05 maka dapat dikatakan bahwa tidak terdapat 
pengaruh yang signifikan antara variabel bebas terhadap variabel terikat secara parsial.

\section{Regresi Linear Berganda}

Regresi linear berganda dilakukan dengan tujuan untuk mengetahui arah pengaruh variabel bebas terhadap variabel terikat, apakah pengaruhnya positif atau negatif. Adapun persamaan regresi linear berganda menurut (Ghozali, 2013) adalah $Y=a$ $+b_{1} X_{1}+b_{2} X_{2}+$ et

\section{Uji Koefisien Determinasi}

Uji koefisien determinasi bertujuan untuk menentukan proporsi atau persentase total variasi dalam variabel terikat yang diterangkan variabel bebas secara bersamasama, sedangkan sisanya dipengaruhi oleh variabel-variabel lain yang tidak dimasukan dalam model regresi atau tidak diteliti oleh penulis (Ghozali, 2013).

\section{HASIL PENELITIAN DAN PEMBAHASAN}

\subsection{Hasil Penelitian}

Data yang digunakan dalam penelitian adalah data primer. Data primer di peroleh dengan cara menyebar kuesioner kepada karyawan PT. Putra Kediangan Propertindo. Kuesioner terkait tentang variabel kepuasan kerja, beban kerja, dan kinerja karyawan. Sampel dalam penelitian ini berjumlah 32 responden. Jumlah sampel diambil berdasarkan tabel data validitas dan reabilitas dengan batas eror $5 \%(0,05)$. Jumlah item indikator yang ada dalam penelitian ini adalah 14 pertanyaan, akan tetapi dikarenakan terdapat dua item yang dinyatakan gugur maka item pertanyaan menjadi 12 item. Pengujian asumsi klasik dilakukan sebelum pengujian hipotesis yang meliputi uji normalitas dan uji homogenitas menggunakan aplikasi SPSS. Hasil uji asumsi klasik adalah sebagai berikut:

\section{Uji Normalitas}

Gambar 1.

Uji Normalitas

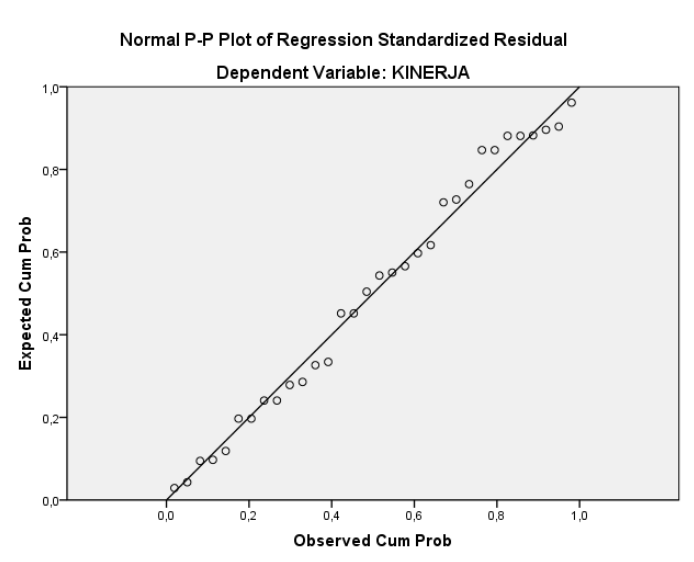

Dari gambar terlihat bahwa data grafik mendekati garis normal, sehingga dikatakan bahwa data memenuhi unsur normalitas.

\section{Uji Homogenitas}

Untuk menguji homogenitas digunakan metode visual berdasarkan hasil olahan data dengan program SPSS yaitu dengan cara melihat penyebaran nilai-nilai residual terhadap nilai prediksi sebagaimana dalam grafik Scatterplot.

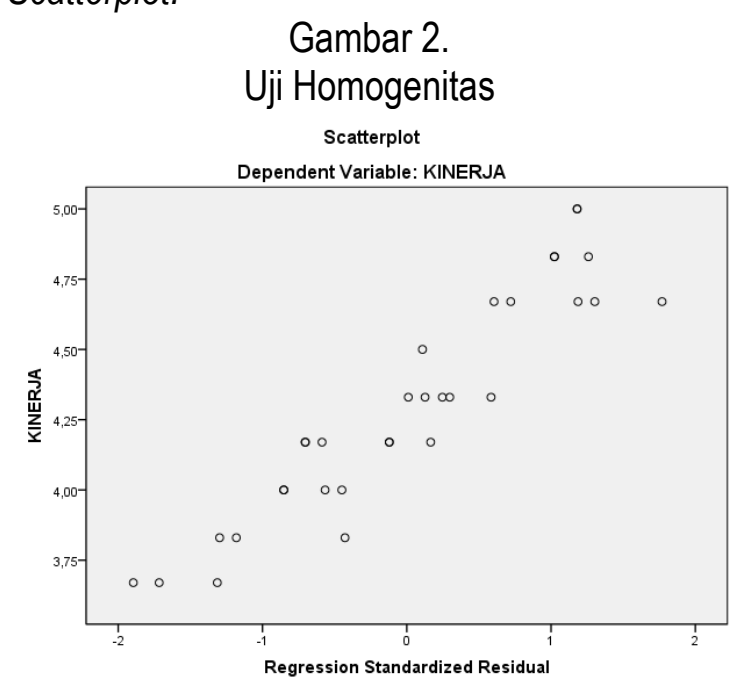

Berdasarkan gambar grafik diatas, diketahui bahwa penyebaran nilai-nilai perbandingan tersebut tidak membentuk pola tertentu dan penyebaran terjadi secara acak yang berarti bahwa asumsi homogenitas dapat terpenuhi.

\section{Uji Statistik F}

Uji F dilakukan untuk melihat pengaruh variabel bebas terhadap variabel terikat secara keseluruhan atau bersama-sama. Dari perhitungan yang telah dilakukan menunjukkan 
bahwa $F$ hitung persamaan regresi sebesar 2,152 (Prob.sig. $=0,134$ ) dan > 0,05 Ini berarti $F$ hitung adalah tidak signifikan. Dengan demikian dikatakan bahwa variabel bebas tidak mampu menerangkan dengan baik variabel terikatnya. Dengan kata lain bahwa variabel kepuasan kerja dan beban kerja secara simultan tidak mempunyai pengaruh yang sangat berarti terhadap perubahan yang terjadi pada kinerja karyawan PT. Putra Kediangan Propertindo.

Tabel 1.

ANOVAb

\begin{tabular}{|c|c|c|c|c|c|c|}
\hline Model & & $\begin{array}{l}\text { Sum of } \\
\text { Squares }\end{array}$ & Df & Mean Square & $\mathrm{F}$ & Sig. \\
\hline \multirow{3}{*}{1} & Regression & 629 & 2 & 314 & 2,152 & ,134a \\
\hline & Residual & 4,237 & 29 & 146 & & \\
\hline & Total & 4,866 & 31 & & & \\
\hline
\end{tabular}

a. Predictors: (Constant), BEBAN, KEPUASAN

b. Dependent Variable: KINERJA

\section{Uji Statistik $\mathrm{t}$}

Uji t dilakukan untuk melihat besarnya pengaruh dari variabel bebas terhadap variabel terikat. Dari hasil estimasi dapat kita lihat bahwa nilai $t$ hitung untuk variabel kepuasan $\left(X_{1}\right)$ sebesar 2,070 (Prob.sig. $=0.047$ ) hal ini menunjukkan bahwa kepuasan berpengaruh secara signifikan terhadap kinerja karyawan. Sedangkan untuk variabel $\left(X_{2}\right)$ sebesar 0,421 (Prob.sig. $=0.677)$ hal ini menunjukkan bahwa beban kerja tidak berpengaruh secara signifikan terhadap kinerja karyawan PT. Putra Kediangan Propertindo.

Tabel 2.

Coefficients $^{\mathrm{a}}$

\begin{tabular}{|c|c|c|c|c|c|c|c|c|c|}
\hline \multirow{2}{*}{ Mode } & & \multicolumn{2}{|c|}{$\begin{array}{c}\text { Unstandardized } \\
\text { Coefficients }\end{array}$} & \multirow{2}{*}{$\begin{array}{c}\begin{array}{c}\text { Standardized } \\
\text { Coefficients }\end{array} \\
\text { Beta }\end{array}$} & \multirow{2}{*}{$t$} & \multirow{2}{*}{ Sig. } & \multicolumn{3}{|c|}{ Correlations } \\
\hline & & B & Std. Error & & & & $\begin{array}{l}\text { Zero- } \\
\text { order }\end{array}$ & Partial & Part \\
\hline \multirow{3}{*}{1} & (Constant) & 2,215 & 1,858 & & 1,192 & ,243 & & & \\
\hline & KEPUASAN & ,332 &, 160 & ,372 & 2,070 &, 047 & ,352 & ,359 & ,359 \\
\hline & $\overline{\text { BEBAN }}$ & , 135 & ,319 &, 076 & ,421 & 677 &,- 023 & ,078 &, 073 \\
\hline
\end{tabular}

a. Dependent Variable: KINERJA

\section{Rigresi Liner Berganda}

Dari hasil pengolahan data dengan menggunakan regresi linier berganda didapatkan hasil persamaan regresi sebagai berikut :

$$
Y=2,215+0,332 X_{1}+0,135 X_{2}
$$

\section{Uji Koefisien Determinasi}

Tabel 3.

Model Summaryb

\begin{tabular}{lllll}
\hline Model & R & R & Adjusted & Std. Error Change Statistics
\end{tabular}




\begin{tabular}{|c|c|c|c|c|c|c|c|c|}
\hline & Square & R Square & $\begin{array}{l}\text { of the } \\
\text { Estimate }\end{array}$ & $\begin{array}{l}\text { R Square } \\
\text { Change }\end{array}$ & $\begin{array}{l}\text { F } \\
\text { Change } \\
\end{array}$ & df1 & df2 & $\begin{array}{l}\text { Sig. F } \\
\text { Change }\end{array}$ \\
\hline ,359a & 129 & ,069 & , 38225 & ,129 & 2,152 & 2 & 29 & 134 \\
\hline
\end{tabular}

Dari hasil perhitungan, koefisien determinasi $\left(R^{2}\right)$ relative kecil yaitu sebesar 0,129. Ini berarti bahwa 12,9 persen dari variasi perubahan kinerja pegawai dapat dijelaskan oleh variasi perubahan variabel yang mempengaruhinya yaitu kepuasan kerja dan beban kerja. Sedangkan sisanya 87,1 persen dijelaskan oleh variabel lain yang tidak dijelaskan dalam model.

\subsection{Pembahasan}

Hasil penelitian menunjukkan bahwa variabel kepuasan kerja berpengaruh positif dan signifikan terhadap kinerja karyawan PT. Putra Kediangan Propertindo. Pengaruh kepuasan kerja terhadap kinerja dapat dijelaskan dengan beberapa faktor. Skor tertinggi indikator kepuasan kerja terdapat pada indikator kepuasan terhadap promosi. Sistem pemberian promosi pada PT. Putra Kediangan Propertindo dilihat berdasarkan kinerja dan kreatifitas yang di kerjakan karyawan. Sedangkan skor terendah terdapat pada indikator kepuasan rekan kerja.

Hal ini menunjukan bahwa karyawan PT. Putra Kediangan Propertindo merasa bahwa rekan kerja kurang bisa diajak kerjasama dengan baik atau mereka bekerja secara individu. Sehingga sangatlah cocok, bahwa (S.P Hasibuan, 2008:202) menyatakan kepuasan kerja adalah sikap emosional yang menyenagkan dan mencintai pekerjaannya. Sikap ini dicerminkan oleh moral kerja, kedisiplinan, dan prestasi kerja.

Berdasarkan definisi diatas, indikatorindikator yang dikembangkan oleh (Celluci, Anthony J dan David L. De Vries dalam Mas'ud, 2004) yang meliputi antara lain:

1. Kepuasan terhadap gaji, yaitu senang atau tidak senang karyawan akan gaji yang diterima.

2. Kepuasan dengan promosi, yaitu sikap senang atau tidak senang karyawan akan promosi yang dilakukan perusahaan.
3. Kepuasan terhadap rekan kerja, yaitu sikap senang atau tidak senang karyawan akan dukungan dari rekan kerjanya.

4. Kepuasan terhadap supervisor, yaitu sikap senang atau tidak senang karyawan akan perlakuan dari pimpinan.

Hasil penelitian ini juga menunjukkan bahwa tidak terdapat pengaruh yang signifikan antara beban kerja terhadap kinerja karyawan PT. Putra Kediangan Propertindo. Pada variabel beban kerja skor tertinggi terdapat pada indikator target yang harus saya capai dalam pekerjaan sudah jelas. Sedangkan skor terendah terdapat pada indikator saya bertanggung jawab menyelesaikan pekerjaan dalam kondisi apapun. Apabila karyawan tersebut memiliki persepsi yang positif maka mereka akan menganggap beban kerja sebagai tantangan dalam bekerja sehingga mereka lebih bersungguh-sungguh dalam bekerja dan menghasilkan sesuatu yang bermanfaat bagi dirinya maupun perusahaan tempat bekerja. Sebaliknya jika persepsi negatif yang muncul maka beban kerja dianggap sebagai tekanan kerja sehingga dapat mempengaruhi kinerja karyawan, memiliki dampak negatif bagi dirinya maupun perusahaan tempat bekerja.

Selanjutnya penelitian ini juga menunjukkan bahwa tidak terdapat pengaruh yang signifikan terhadap kepuasan kerja dan beban kerja terhadap kinerja karyawan PT. Putra Kediangan Propertindo. Pada variabel kinerja skor tertinggi terdapat pada indikator efisiensi kerja yang melebihi rata-rata karyawan lain. Sedangkan skor terendah terdapat pada indikator ketepatan yang bagus dalam melaksanakan pekerjaan. Dari hasil pengujian menunjukkan bahwa nilai untuk signifikansi antara variabel kepuasan kerja dan beban kerja terhadap kinerja kayawan yaitu sebesar 0,134 yang berarti $<0,05$ sehingga hipotesis pada penelitian ini diterima dan $\mathrm{H}_{\mathrm{a} 3}$ ditolak. Artinya tidak ada pengaruh kepuasan kerja dan beban kerja terhadap kinerja karyawan secara simultan.

\section{SIMPULAN DAN SARAN}


Secara parsial Terdapat pengaruh yang positif dan signifikan antara variabel kepuasan kerja dan beban kerja terhadap kinerja karyawan PT. Putra Kediangan Propertindo. Secara simultan terdapat pengaruh yang signifikan dari variabel kepuasan kerja dan beban kerja terhadap kinerja karyawan PT. Putra Kediangan Propertindo. Persamaan besarnya variasi kinerja karyawan yang ditentukan oleh kepuasan kerja dan beban kerja adalah adalah 12,9 persen ( $R$ sequare $=0,129$ ). Angka $R$ square adalah 0,129 ini berarti sebesar 12,9\% kinerja pegawai di pengaruhi oleh variabel kepuasan kerja dan beban kerja. Sedangkan sisanya $87,1 \%$ dipengaruhi oleh faktor-faktor lain diluar variabel penelitian ini.

\section{DAFTAR PUSTAKA}

Adityawarman,Yudha, Bunasor Sanim dan Bonar M Sinaga. 2015. Pengaruh Beban Kerja Terhadap Kinerja Karyawan PT. Bank Rakyat Indonesia (Persero) Tbk Cabang Krekot. Jurnal Manajemen dan Organisasi Vol. VI, No. 1, April 2015

Arikunto, Suharsimi. 2010. Prosedur Penelitian: Suatu Pendekatan Praktek. Jakarta: Rineka Cipta

Arpan, Y., \& Diaspri, B. B. (2015). ANALISIS LOYALITAS MEREK KENDARAAN MITSUBISHI L300. JURNAL STIE GENTIARAS, 7(1), 34-46.

Artadi, Febri Furqon. 2015. Pengaruh Kepuasan Kerja dan Beban Kerja Terhadap Kinerja Karyawan Pada PT. Merapi Agung Lestari. Skripsi Universitas Negeri Yogyakarta

As'ad, M. 2003. Psikologi Industri: Seri Sumber Daya Manusia. Yogyakarta: Liberty

Bangun, Wilson. 2012. Manajemen Sumber Daya Manusia. Bandung: Erlangga

Cain, B. 2007. A Review of The Mental Workload Literature. Canada: Human System Integration Section

Dessler, Gary. 2011. Human Resource Management Fourth Edition. New Jersey: Pearson Prentice Hall

Ghozali, Imam. 2013. Aplikasi Analisis Multivariate Dengan Program IBM SPSS21 Update PLS Regresi.
Semarang: Badan Penerbit Universitas Diponegoro

Gomes, Faustino Cardoso. 2001. Manajemen Sumber Daya Manusia. Yogyakarta: Penerbit Andi Offset

Handoko, T. Hani. 2001. Manajemen Personalia dan Sumberdaya Manusia. Yogyakarta: BPFE

Nugroho, H. (2015). ANALISIS PROGRAM KEMITRAAN DAN BINA LINGKUNGAN (PKBL) PTPN VII DI PROPINSI LAMPUNG. JURNAL STIE GENTIARAS, 7(2), 177-187.

Mangkuprawira S dan Hubeis AV. 2007. Manajemen Mutu Sumber Daya Manusia. Jakarta: Ghalia Indonesia

Manuaba, A. 2000. Ergonomi, Kesehatan dan Keselamatan Kerja. Surabaya: Guna Widya

Martoyo, Susilo. 2000. Manajemen Sumber Daya Manusia. Yogyakarta: BPFE

Mas'ud, Fuad. (2004). Survai Diagnosis Organisasional, Konsep dan Aplikasi. Semarang: Badan Penerbit Universitas Diponegoro

Munandar, A.S. 2001. Psikologi Industri dan Organisasi. Depok: Penerbit Universitas Indonesia (UIPress)

Peraturan Menteri Dalam Negeri Nomor 12 Tahun 2008 Tentang Pedoman Analisis Beban Kerja Di Lingkungan Departemen Dalam Negeri Dan Pemerintah Daerah

Prihartono dan Purwondoko. 2006. Pemetaan Kebutuhan Pegawai Dengan Pendekatan Pengukuran dan Analisis Beban Kerja PT. Indonesia Tower

Putra, A. S. (2012). Analisis Pengaruh Beban Kerja Terhadap Kinerja Karyawan Divisi Marketing dan Kredit PT. WOM Finance Cabang Depok. Skripsi Institut Pertanian Bogor

Riani, Laksmi. 2013. Manajemen SDM Masa Kini. Yogyakarta: Graha IImu

Rivai, Veithzal. 2010. Manajemen Sumber Daya Manusia Untuk Perusahaan Dari Teori Ke Praktik. Jakarta: Raja Wali Pers

Robbins, Stephen P. dan Judge. 2009. Perilaku Organisasi. Jakarta: Salemba Empat

Ruky, S. Achmad. 2004. Sumber Daya Manusia Berkualitas. Jakarta: PT. Gramedia Pustaka Utama

Sedarmayanti. 2003. Pengembangan Kepribadian Pegawai. Bandung: Mandar Maju 
Simanjuntak, Payaman J. 2005. Manajemen dan Evaluasi Kerja. Jakarta: FE UI

Sinambela, dkk. 2012. Kinerja Pegawai. Yogyakarta: Graha IImu

Sinamo, Jansen H. 2007. Delapan Etos Kerja Profesional. Jakarta: Penerbit Institut Darma Mahardika

Sugiyono. 2013. Statistik Untuk Penelitian. Bandung: Alfabeta

Syaiin, Subakti. 2008. Pengaruh Kepuasan Kerja Terhadap Kinerja Pegawai Klinik
Spesialis Bestari Medan. Tesis Sekolah Pascasarjan Universitas Sumatera Utara Medan

Widjajanta, B. Dan A. Widyaningsih. 2009. Mengasah Kemampuan Ekonomi 1: untuk kelas $X$ Sekolah Menengah Atas/Madrasah Aliyah Program IImu Pengetahuan Sosial. Pusat Perbukuan, Departemen Pendidikan Nasional, Jakarta. p. 170 